\title{
Endemic Marsh Mongoose Herpestes palustris (Carnivora: Herpestidae) of East Kolkata Wetlands, India: a status report
}

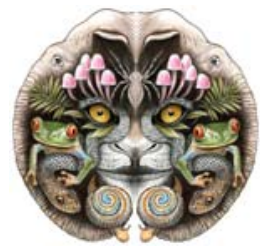

\author{
Jayanta Kumar Mallick
}

Personal Assistant to Principal Chief Conservator of Forests, Wildlife \& Biodiversity, West Bengal Office Wildlife Wing, Directorate of Forests, Govt. of West Bengal, Bikash Bhawan, North Block, $3^{\text {rd }}$ Floor, Salt Lake City, Kolkata, West Bengal 700091, India

Email: jayantamallick2007@ rediffmail.com

Date of online publication 26 April 2009 ISSN 0974-7907 (online) | 0974-7893 (print)

Editor: C. Srinivasulu

\section{Manuscript details:}

Ms \# 01936

Received 06 February 2008

Final received 03 April 2009

Finally accepted 04 April 2009

Citation: Mallick, J.K. (2009). Endemic Marsh Mongoose Herpestes palustris (Carnivora: Herpestidae) of East Kolkata Wetlands, India: a status report. Journal of Threatened Taxa 1(4): $215-220$

Copyright: () Jayanta Kumar Mallick 2009. Creative Commons Attribution 3.0 Unported License. JoTT allows unrestricted use of this article in any medium for non-profit purposes, reproduction and distribution by providing adequate credit to the authors and the source of publication.

Author Details: Jayanta Kumar Mallick Postgraduated in 1974, joined the Wildlife Wing (Headquarters) in 1976 and has been working as PA to PCCF, Wildlife, West Bengal, for the last 33 years. He has been involved in all departmental publications, has participated in departmental workshops, undertaken a number of studies, is looking after departmental data bank and has about fifty published articles and study reports on wildlife conservation.

Acknowledgements: Shri Sampat Singh Bist I.F.S., ex-PCCF, Wildlife \& Biodiversity, West Bengal; Shri N.C. Bahuguna, I.F.S., Director, Sundarban Biosphere Reserve; Shri Biswaji Roy Chowdhury, Secretary, Nature Environment \& Wildlife Society \& Editor "Environ", Kolkata; Shri Subrata Pal Chowdhury, Technical Assistant; Shri Indranil Mitra; Shri Somnath Chakraborty and Rabindra Nath Mistry (Wildlife Wing, Headquarters)
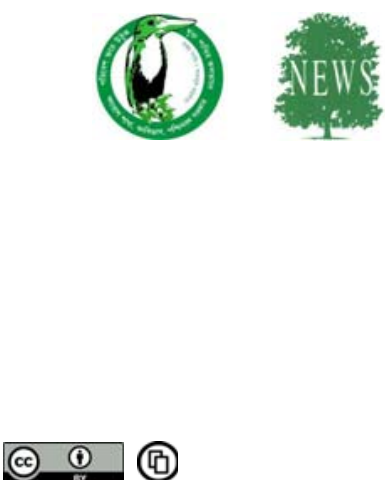

OPEN ACGESS | FREE DOWNLOAD
Abstract: Marsh Mongoose Herpestes palustris is the only extant endemic mammal of the East Kolkata wetlands, which has been declared a RAMSAR site in 2002. Since its first description by the scientists of the Zoological Survey of India, the population of this species has dwindled to an alarming state due to reclamation of the Salt Lake City and Rajarhat expansion, as well as from other anthropogenic causes. Recently, during a field survey only a small population of this endangered mongoose was found in a single location. Immediate conservation measures are required to be taken by the concerned authorities to stop its probable extinction in the near future.

Keywords: Endemic, Marsh Mongoose, Herpestes palustris, mammal, East Kolkata wetlands, Salt Lake, Zoological Survey of India, taxonomy, habitat, conservation, status

Abbreviations: H\&B - length of head and body; $\mathrm{TI}$ - length of tail; $\mathrm{Hf}$ - length of hindfoot; $\mathrm{E}$ - length of ear; I - length of the skull; cb - condylobasal length; mw - maxillary width; iw - least interorbital width; pow - postorbital width; $\mathrm{pm}^{4}$ - length of fourth upper premolar; $\mathrm{ml}$ - mandibular length; $\mathrm{zw}$ - zygomatic width.

\section{Bengali Abstract:}

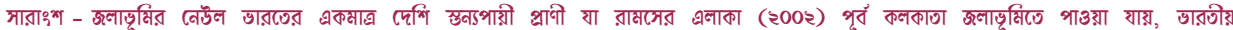

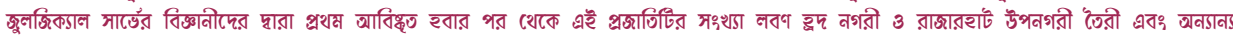

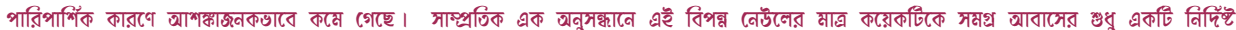

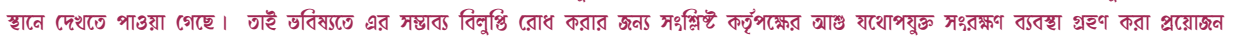

\section{INTRODUCTION}

About $11 \%$ of Indian mammalian species are endemic, with the Western Ghats being the prime endemic zone, followed by the Deccan Peninsula and the Andaman \& Nicobar Islands. For the majority, detailed information is not available regarding their biology and population status. Many species are known only by the type series or even by single type specimen, and have not been recorded since their original description.

Similarly, endemism in wetland fauna is poorly known. Among vertebrates, one species of mammal, namely the Marsh Mongoose Herpestes palustris (reported as a new species from Salt Lake swamp of West Bengal in 1965), 44 species of water birds and 223 species of fish are known to be endemic to the Indian wetlands (Alfred \& Nandi 2000). Information regarding the socio-biology and present status of the endemic Bengal or Salt Lake Marsh Mongoose is scanty given its distinctive features, compared to the other species of the same genera sharing the same wetland habitat, i.e. H. auropunctatus (Hodgson 1836), pointed out by the scientists of the Zoological Survey of India about 42 years ago. The land-use pattern of its habitat in the East Kolkata Wetlands (hereinafter referred to as EKW), extending over $125 \mathrm{~km}^{2}$, is agriculture (vegetable cultivation: $4.67 \mathrm{~km}^{2}$ and paddy cultivation: $48.88 \mathrm{sq} . \mathrm{km})$ and aquaculture $\left(47.79 \mathrm{~km}^{2}\right)$. Though classified as wetlands, only $23.66 \mathrm{~km}^{2}$ is left out of such direct human activities. The paleo-environment of these wetlands was an extension of the Sundarban mangroves.

Formulation and implementation of a species-specific conservation action plan for this dwindling endemic mongoose is urgently needed. In the year 2002 the EKW was declared formally as a conservation area of international importance. The floral and faunal diversity of this wetland was assessed and field surveys were conducted to understand the present day status of the Marsh Mongoose in the wetland. Studies show that urgent conservation measures have to be taken up for the long-term sustenance of the Marsh Mongoose against anthropogenic threats (Sanyal 1999; Walker \& Molur 1999; Dey 2007).

\section{Materials and Methods}

The Marsh Mongoose was specifically recorded by Ghose (1965), Ghose \& Chaturvedi (1973), Schreiber et al. (1989), Agrawal et al. (1992), Ewer (1997), Agrawal (1998), 

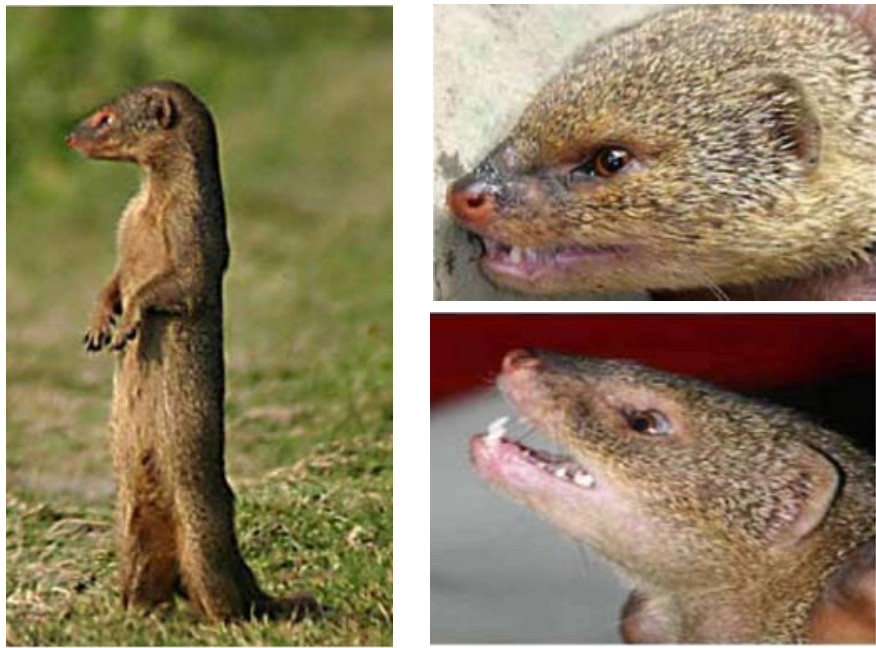

Images 1-3. Marsh Mongoose (Herpestes palustris).

Courtesy: Nature, Environment \& Wildlife Society (NEWS).

Molur \& Walker (1998), Hussain (1999), Sanyal (1999), Captive Breeding Specialist Group (2000), Chattopadhyay (2001), Alfred \& Chakraborty (2002), Alfred et al. (2002), Anonymous (2004), Dey (2007), and Mallick (2007). The latest field study on this species was conducted by Nature, Environment and Wildlife Society (NEWS), Kolkata, during 2005-06.

Surveys were conducted by NEWS in different marshy and swampy areas of the 24-Parganas districts of lower West Bengal. Based on interviews with the local people, fishermen and scientists of the Zoological Survey of India (ZSI), the following wetlands of East Kolkata Wetland (included in the RAMSAR Site) - Nalban Fishery, 4 No Bhery, Sarder Bhery, Noter Bhery, Sahebmara Bhery, Chinta Sing Bhery, Goltala Fish Project, Chokher Bhery and Gopeswar Bhery - were selected for survey.

Direct observations were made to identify the habitats with surviving populations. Random trapping with Japanese wire traps was carried out in all the identified habitats for six consecutive months daily from 0630 to $1100 \mathrm{hr}$, and from 1500 to $1700 \mathrm{hr}$. Live chicks of country chickens were put inside the trap as bait. The traps were placed near the burrows of mongoose under the camouflage of leaves of water hyacinth. Field workers observed the traps from a distance of at least $3 \mathrm{~m}$ with binoculars, whenever necessary. In all six Marsh Mongooses, including a 1-year old juvenile female, two adult females and three adult males, were trapped. First, the trapped mongooses were immobilized with chloroform, then their weight and length were measured. Before releasing them in the wild, they were marked with black hair dye to avoid measuring the same individuals again, if trapped.

In addition, the indirect method of burrow count was followed in the pre-selected occupied niches of this species falling within their territorial range. Active burrows are noted by the closing of the burrow mouth with clay by the mongooses in the late evening after their entry into the nests. Active burrows were counted the next day in the morning (0730 to $0800 \mathrm{hr}$ ) and their locations marked on a map.

\section{Study Area}

EKW $\left(22^{\circ} 25^{\prime}-22^{\circ} 40^{\prime} \mathrm{N} \& 88^{\circ} 20^{\prime}-88^{\circ} 35^{\prime} \mathrm{E}\right)$ is a multiple-use zone to the east of the mega-city and includes a garbage dump (known as Dhapa Square Mile and used as such since the mid1800 s), a mosaic of vegetable fields, a series of 300-odd fishponds connected by major and secondary canals, rice fields, wholesale markets, a few roads, and 43 villages (with a population of about 60,000). The ownership pattern of the sewage-fed fisheries is - Private: $93.14 \%$; Cooperative: $0.86 \%$ and Government: 6\%.

The EKW extends almost equally on both sides of a dry weather flow channel, which discharges into the Kulti Gong (the wastewater outfall), $28 \mathrm{~km}$ to the east of Kolkata. Geomorphologically, these wetlands form an inter-distributory marsh of the Hoogly-Bidyadhari (silted and choked in 1930s) system over about $76 \mathrm{~km}^{2}$. Early records show that even in the middle of the $18^{\text {th }}$ century the western margin of the Salt Lake was within $3 \mathrm{~km}$ from the river Hooghly. The system reached peak productivity in the middle of the $20^{\text {th }}$ century but is declining due to encroachment and development fed by a real estate boom starting from the end of the 1980s.

\section{Conservation Significance}

The EKW presently possess considerable biodiversity value in terms of species - 104 plants, 16 mammals, 66 aves, four crustaceans, 14 aquatic insects, 10 mollusks, 20 reptiles, four amphibians and 37 fishes (Dasgupta 1973; Chowdhury 1984; De et al. 1989; Ghosh 1990; Nandi et al. 1993; Ghosh 1997; Chattopadhyay 2001; Anonymous 2004).

EKW were first protected by an order of the Calcutta High Court in 1992, prohibiting any change in the land use. After a decade, on 19th August, 2002, these wetlands were declared as a RAMSAR Site, the only one in West Bengal, by the RAMSAR Convention Bureau.

\section{Taxonomy of Herpestes palustris}

The taxonomic status of some species of mongoose is still controversial and requires further study with fresh specimens (Alfred \& Chakraborty 2002). The taxonomy of the Marsh Mongoose, like other species of the genus Herpestes, is also confused. It now belongs to the Ichneumon or Mongoose family Herpestidae (Bonaparte 1845). It was earlier included under Family Viverridae, the Civet Family (Ellerman \& MorrisonScott 1951; Ghose 1965; Chakraborty 1989) because it was believed to be descended from the civet-like mammals. But, herpestids are differentiated from viverrids by their rounded ears and presence of anal glands (not perianal glands).

This species was first described by R.K. Ghose (1965) separating it from $H$. auropunctatus on the basis of skin and skull of adult male. Agrawal et al. (1992) also maintain the same status accepting the distinguishing characters mentioned by Ghose (1965). It is still considered a valid subspecies of Herpestes javanicus (E. Geoffroy Saint-Hilaire 1818) by Wozencraft (2005). Honacki et al. (1982) synonymized $H$. palustris with H. (Mangusta) auropunctatus (Hodgson 1836). Wenzel \& Haltenorth (1972) and Corbet \& Hill (1992) considered palustris, auropunctatus and javanicus as conspecific, whereas Ewer (1997), based on Ghose's observation that H. palustris can emit anal scent similiar to $H$. urva, speculated on such a relationship to H. urva (Hodgson 1836). According to the recent (2005-06) study on the species with fresh series of H. palustris specimens, the original (1965) species identification of the present population in EKW has been corroborated. 


\section{Live specimens collected}

The species was originally recorded from three districts Howrah District, north 24-Parganas District (Ghose 1965) and south 24-Parganas District (Ghose \& Chaturvedi 1973). It is suspected to be found in other neighbouring districts of the confirmed locations, but there is no concrete evidence behind this. It was first discovered from the marshy and swampy areas in the eastern part of Kolkata City on the left bank of the river Hooghly. Twenty-seven specimens of both sexes were collected by B. Biswas during January-December, 1965 from Salt Lake, Bantala, Duttabad, Hederhat, and Nalban areas. During that period, the species was fairly common in Salt Lake and other marshy areas near Kolkata. This species was also recorded from Botanical Garden, Shibpur on the right bank of the Hooghly River (one specimen collected by B. Biswas on 25.xi.1964), Najimganj, south of Botanical Garden at Shibpur (Howrah) (one specimen collected by R.K. Ghose on 26.i.1965), Diamond Harbour (south 24 Pgs.) and Sukhchar, c. $16 \mathrm{~km}$. north of Kolkata (north 24 Pgs.) (one specimen collected by B. Biswas on 02.viii.1964). Two more locations, viz. Patiatala and Bajbaj, were recorded by S. Chattopadhyay, N.V.K. Ashraf and G. Christopher (Walker 1999). The study, conducted by Nature Environment and Wildlife Society, Kolkata, in the Nalban Fishery, 4 No Bheri, Sarder Bheri, Noter Bheri, Sahebmara Bheri, Chinta Sing Bheri, Goltala Fish Project, Chokher Bheri and Gopeswar Bheri within East Kolkata Wetland through random trapping during 2005-06, reports that the whole population of mongoose in north Salt Lake bheri areas is constituted of Herpestes palustris as no other sympatric species of this genus was found to be trapped during the same study.

\section{Species description}

There appear to be 37 recognized species of mongoose in the world. The latest is the Bengal or Salt Lake Marsh Mongoose, Herpestes palustris, a small cat-like carnivore. Three more species of the genus Herpestes (Illiger 1811) occur in West Bengal. These are: Small Indian Mongoose (H. javanicus auropunctatus), Indian Grey Mongoose (H. edwardsi) and Crabeating Mongoose (H. urva Hodgson 1836), of which the first two species are sympatric and the third allopatric (being inhabitants of northern Bengal and northeastern India) with Marsh Mongoose. Moreover, H. urva is a large-sized mongoose (HBL: $45-57 \mathrm{~cm}$ and Tl: $30-35 \mathrm{~cm}$ ) characterized by a white stripe running from the angle of the mouth to the side of the neck. But compared to the other two mongoose species, H. javanicus auropunctatus is common in EKW (Anonymous 2004).

On an average ( $\mathrm{n}=6$ trapped individuals), an adult female marsh mongoose weighs $500-625 \mathrm{~g}$, length from tip to tail $56-$ $58 \mathrm{~cm}$, body length $30-32 \mathrm{~cm}$ and tail length $25-27 \mathrm{~cm}$. Similarly, an adult male weighs $625-900 \mathrm{~g}$, length from tip to tail $61-63 \mathrm{~cm}$, body length $32-36 \mathrm{~cm}$ and tail length $26-28 \mathrm{~cm}$ (NEWS 200506). Veron et al. (2007) record head and body length of $H$. auropunctatus in the Indian subcontinent as $25-32 \mathrm{~cm}$. Agrawal et al. (1992) have also given the following external measurements of the collected samples of both males and females (all measurements in $\mathrm{mm}$; range with mean in parenthesis).

Morphometrics: 15 males: H\&B 284.5-365.0(335.0); Tl 224.0-235.0(263.0); Hf 54.5-63.5(58.0); E.17.7-26.5(24.0). 4 females: H\&B 303.0-3 15.0(309.0); Tl 240-258.0(249.0); Hf 51.0-54.O(52.7); E.21.1-24.O(22.5). Cranial:14 males : 1 62.772.3(68.0); cb 62.3-71.5(67.1); mw 10.4-12.9(11.5); iw 10.3-
12.1(11.2); pow 8.6-13.8(10.3); $\mathrm{pm}^{4}$ 5.7-6.3(6.0); ml 4.8$5.8(5.5)$; zW 29.8-34.6(32.2). 4 females: 1 61.8-63.5(62.9); cb 60.9-63.2(62.0); mw 10.1-10.9(10.6); iw 9.8-11.0(10.5); pow 9.6-13.1(11.1); $\mathrm{pm}^{4}$ 5.6-6.1(5.8); ml 5.0-5.8(5.4); zw 29.532.6(30.6).

Morphology: It has a small head, long face and vermiform body, small and rounded ears, mostly concealed by hairs, short legs and long muscular tail, thick at the base, and tapering at the end. Its fur is rough and coarsely grizzled (Alfred \& Chakraborty 2002). It has semi-plantigrade feet with short compressed claws, which are non-retractile and are used for digging. Its eyes are small, but glittering and snake-like, with linear erect pupils. The tongue is rough as a cat's. The female has only four mammae.

It is similar to Small Indian Mongoose in some respects but varies in others (Ghose 1965). NEWS (2005-06) also consulted the skin rolls of specimens, preserved by Zoological Survey of India, Kolkata, for noting the major morphological differences between Herpestes palustris and H. auropunctatus. It appears that in $H$. auropunctatus the muzzle is dark brown and cranium gradually narrows from the orbit, whereas in H. palustris the muzzle is black and the cranium narrows abruptly behind the orbit so that postorbital region appears as a constriction between frontals and cranium (Agrawal et al. 1992). Whereas the fully grown contour hairs of H. edwardsi nyula is long, many banded and usually coarse, the contour hairs of $H$. auropunctatus is short, soft, with a few bands. The legs of Indian Grey Mongoose are darker than body, but those of Small Indian Mongoose are not darker than the body. However, during 2005-06, not a single Small Indian Mongoose was trapped from the spots identified by NEWS and the inference is drawn by them that the whole population of mongoose in north Salt Lake bhery areas is constituted of Herpestes palustris.

There is intra-specific variation (Alfred \& Chakraborty 2002). It is dimorphic in colour, having both dark and light forms. In the dark form, individual contour hair is alternately banded with black and buff-yellow, while in light form, it is blackish-brown and straw yellow (Alfred \& Chakraborty 2002).

\section{Habitat and Associates}

It is predominantly terrestrial (partly aquatic) and fossorial animal. It inhabits large but shallow water bodies covered with thick growth of aquatic and herbaceous vegetation, that is, wetland-bogs, brackish marshes, swampy edges infested with reeds, the emergent hydrophytes, such as Phragmites karka (Retz.) and Typha angustifolia L. (Biswas 1927). Various air breathing fish, frogs, insect larvae, snails, crabs and medium to small mammals live on the resources of these wetlands (Sewel 1934). Its associate terrestrial mammalian species are Prionailurus viverrinus Bennett (Fishing Cat), Lutrogale perspicillata Geoffroy (Smooth-coated Otter), Herpestes javanicus auropunctatus (Small Indian Mongoose), Herpestes edwardsii (Indian Gray Mongoose), Viverricula indica (Small Indian Civet), Paradoxurus hermaphroditus (Common Palm Civet or Tody Cat), Felis chaus (Jungle Cat), Canis aureus (Jackal), Bandicota indica Bechstein (Greater Bandicoot Rat), Bandicota bengalensis (Lesser Bandicoot Rat), Mus booduga (Common Indian Field Mouse), Mus platythrix (Indian Brown Spiny Mouse) and Suncus murinus (Gray Musk Shrew), all depend on these wetlands for food and shelter. 


\section{Behavioural pattern}

The Marsh Mongoose, besides living in the self-dug burrow, also occupies other's burrows, mainly along the slopes of water bodies (NEWS 2005-06). It appears that the area surrounding the occupied burrow is devoid of such clay particles unlike those of large bandicoot rats and fresh scratch marks are seen near the mouths of mongoose-burrows.

It is mainly diurnal and exhibits a routine exit-entry movement, coming out of the burrow few hours after sunrise, following a particular route for foraging in its territorial range and returning to the burrow just before sunset. It is described as mostly solitary but occasionally gregarious and found in small troupes, particularly in the afternoon (NEWS 2005-06). This may help in successful joint hunting. Pairing during the breeding season is also seen.

It is a predator and opportunistic omnivore. It preys on crustaceans, mollusks, crabs, amphibians, small reptiles, birds, their eggs, insects and larvae. It is a good rat-hunter. Occasionally, it takes snakes and frogs, but feeds mainly on fish and the common aquatic snail Pila globosa. Sometimes it eats a wide variety of fruits, tubers and berries as well as smaller mammalian species which it may overpower. It often scampers off with its prey for consuming it conveniently.

It adopts different techniques for hunting different types of prey. The most interesting of such techniques is that it frequently goes to the water body searching for fish through the bed of water hyacinth without being submerged in the water. Only its feet become wet in this process. It also wades along pond banks, poking its hands into crevices and sifting through mud to unearth frogs and crustaceans. While hunting, it occasionally stands up on its hind legs. For example, after seizing it throws snails and crabs against hard base from a standing position in order to break shells open. For consuming the eggs it uses its fore-paws to hold the egg, cracking a little hole at the small end to suck out the yolk. Exceptionally, as per local reports, it was seen to hunt a Cattle Egret (Bubulcus ibis coromandus Boddaert, a common resident wader or marsh bird) by seizing it by the throat. When fighting with a snake, it takes care that the snake does not envenomate it. If it is a nonpoisonous prey, the task becomes easier for the predator.

It is alert, ferocious and courageous animal, particularly when the young accompanies the mother. If enraged, it can make its body swell as a result of the erection of the body hairs. It can squirt out a fetid fluid from its anal glands similar to Herpestes urva (Crab-eating mongoose), which acts as a means of self-defence or territorial marking. It is generally silent, but sometimes mews, varying with low yelps or growling in rage with bristling of the hair, particularly of the tail.

In general, the herpestids attain sexual maturity within a year. The females are polyoestrus, breeding twice a year; but breeding time is not fixed. Their gestation period is around 45 days and litter size 2-4. They live for about 10 years. But the details regarding the breeding of Marsh Mongoose are not known. However, the courtship and mating usually starts in the early summer, that is, March onwards, and pups are seen during early June (NEWS 2005-06; Dey 2007).

\section{Status}

H. palustris is the only endemic species of mammal in the Indian wetlands, found in West Bengal. However, no species specific action plan has been formulated for the conservation of species and its habitat.

The Marsh Mongoose was originally included under Schedule IV of the Indian Wildlife (Protection) Act, 1972 and has been upgraded to Schedule II of the Indian Wildlife (Protection) Act, 1972 (Amendment Act 2002), vide Notification No.S.O.1085(E), dated $30^{\text {th }}$ September, 2002 and recorded as 'Endangered' following the IUCN criteria (Molur et al. 1998; Hussain 1999; CBSG 2000; Hilton-Taylor 2000; Alfred et al. 2002; Alfred \& Chakraborty 2002; Dey 2007), but its earlier status was Lower Risk/least concern (Baillie \& Groombridge 1996).

Agrawal et al. (1992) remark, "Prior to reclamation of the Salt Lake, north 24-Parganas District, it was very common in that area. However, at present it is rarely seen there due to habitat destruction". During the $21^{\text {st }}$ century it is reported in one study from only one sample area of EKW, that is, Sahebmara bheri to the western side of the EKW and its status in this particular area was given as 'rare', but it was not recorded from other four study areas, namely, Choubhaga (south), Bantala (south east), Jhagra Sisa (east) and Mahisbathan (north) (Anonymous 2004). Earlier it was very common around water bodies of 24-Parganas (De 1994). However, Nandi et al. (1993) could not find this species in the wetlands of north and south 24-Parganas.

Besides trapping, on an average, 11 to 13 Marsh Mongoose have been counted per stretch of half kilometer in the study area by NEWS (2005-06) with the help of burrow count method. But, since it is a part of the sample survey based on indirect method of counting, the actual population of Marsh Mongoose in EKW could not be estimated.

\section{Threats}

Molur et al. (1998) pointed out the threats like catastrophic events, edaphic factors, human interference, loss of habitat and fragmentation. The halophytic vegetation of the Sundarbans during early 1930s largely dominated the East Kolkata cluster of wetlands (Biswas 1927; Dasgupta 1973). Later on, a gradual change has taken place in water quality from polyhaline condition to almost fresh water with a change in the profile of flora and fauna of the region. Polarization began in 1953. But the most important and massive land use change was caused by urbanisation initiated by the government of West Bengal since 1956. Large-scale reclamation of this wetland started in the 1960s. Thus, out of 20,000 acres of wetlands recorded in 1945, now less than 10,000 acres are left as wastewater fish ponds (Ghosh 2004). Besides, the ecological character of the area is adversely affected by industrial effluents, encroachments, etc. By $1968,36 \mathrm{~km}^{2}$ of the northern Salt Lakes and $34 \mathrm{~km}^{2}$ of the southern Salt Lakes had been reclaimed leading to a rapid decline in the population of this endemic mammal (Agrawal et al. 1992). Another satellite township at Rajarhat is proposed over $30.75 \mathrm{~km}^{2}$ at the cost of the same type of landscape.

Moreover, changes in land use pattern over a period of time have led to conversion of some of the largest fish farms from pisciculture to paddy cultivation and changes in hydrological regimes are affecting ecological balances and functions. Another problem in the hydrology of EKW is arsenic. The percentage of arsenic which is considered safe for consumption is $10 \mathrm{mg} / \mathrm{l}$ as estimated by World Health Organization. However, in the northern limits of greater Kolkata, in the areas like Bhangar, Kharibari, Rajarhat, Bishnupur I and II, Gangra, Mahisbathan II the levels of arsenic has been found to be $10-15 \mathrm{mg} / \mathrm{l}$. 
Additionally, large numbers of industries dump effluents without treatment into the recently laid sewers that empty into the city outfall channels flowing eastwards. This has caused substantial amount of metal deposition in the canal sludge and rendered the waste water incapable of ensuring the edible quality of the fish and vegetables grown in the wetland.

The mongooses are also illegally hunted for their fur for use in the paintbrush industry. Because the hairs are pliant, soft and the tip tapering to a fine point, these are preferred by both students and artists. Mongoose hair makes versatile, durable brushes for oil, tempera, and acrylic painting. Each animal yields about $10 \mathrm{~g}$ of hair. Mongoose hair brushes can be identified by a circular dark brown tip, cream coloured centre, and dark roots (MacDonald 2001).

\section{Conclusions}

Since the declaration of EKW as RAMSAR site for conservation of wetland ecosystem, it has become a mandate for policy makers and planners to have an understanding regarding the in situ situation of this ecosystem. Though the biodiversity assessment of EKW has already been completed, its betterment and development by harnessing the imminent threats through conservation work programmes has to be attained with the right earnest. Time-framed and prioritized action programmes for conservation of the only extant endemic Marsh Mongoose, whose morphometry and external characters distinguishes it from $H$. javanicus auropunctatus, of the Indian wetlands are necessary to be implemented urgently in order to save it from extinction. Although conservation breeding for this endemic species have recommended on the ground that there is no captive population in India or any other country (Walker \& Molur 1999), no followup action has yet been taken in this regard.

The reasons for the species vanishing from one of the largest peri-urban wetlands in the country are massive changes in land use, conversion of wetlands and wilderness areas into built up urban settlements and also due to changes in the fisheries practices. It is noteworthy that, among other plant species, Aldrovanda vesiculosa became extinct from this region during the late $20^{\text {th }}$ century (Cook 1996). Like this species, several other wetland plants may become extinct if the environmental condition are not properly maintained from the ecological point of view. It is an indication of habitat destruction of this important wetland.

During 1964-69 a total of 248 bird species were recorded by the Zoological Survey of India in this region. Among them 109 avian species ( $50 \%$ aquatic) have become locally extinct (Ghosh 2004). For example, the eagles were last seen here in 1992 (Unpublished report of Prakriti Samsad, an Non-Government Organization of Kolkata), 15 wild fish (Sen 1941) and 12 reptilian species (Sewel 1934) have become rare here. Among mammals, Herpestes edwardsii, Viverricula indica, Paradoxurus hermaphroditus, Felis chaus, Canis aureus and Lutrogale perspicillata have also become rare in EKW along with Herpestes palustris (Anonymous 2004). Hence, this is an 'alarm call' for protection of the dwindling population of Herpestes palustris and other rare wild denizens of EKW.

The Marsh Mongoose H. palustris Ghose, 1965 is distinct from the H.javanicus auropunctatus (Hodgson, 1836) in terms of both morphological and cranial characters and we are of the opinion that this species needs to be resurrected out of the syn- onymy of H. javanicus.

\section{References}

Agrawal, V.C. (1998). Faunal diversity in India: Mammalia, pp. 459-469. In: Alfred, J.R.B., A.K. Das \& A.K. Sanyal (eds.). Faunal Diversity in India (A commemorative volume in the $50^{\text {th }}$ Year of India's Independence). ENVIS Centre, Zoological Survey of India, Kolkata, 497pp.

Agrawal, V.C., P.K. Das, S. Chakraborty, R.K. Ghose, A.K. Mandal, T.K.Chakraborty, A.K. Poddar, J.P. Lal, T.P. Bhattacharyya \& M.K. Ghosh (1992). Mammalia, pp. 105-107. In: Director, Zoological Survey of India (ed.). Fauna of West Bengal, Part I, Overview, Mammalia, Aves and Wildlife. Zoological Survey of India, Kolkata, $443 \mathrm{pp}$.

Alfred, J.R.B. \& N.C. Nandi (2000). Faunal Diversity in Indian Wetlands. Enviro News 4(4\&5)[April-May]:no pagination. <http:envfor.nic.in/ news/4500/faunal.html $>$ Downloaded on $2^{\text {nd }}$ January 2007.

Alfred, J.R.B., N.K. Sinha \& S. Chakraborty (2002). Checklist of Mammals of India Records of Zooogical Survey of India, Occasional Paper No. 199: 54, 108-109. Zoological Survey of India, Kolkata, 289pp.

Alfred, J.R.B. \& S. Chakraborty (2002). Endemic Mammals of India, Records of Zooogical Survey of India, Occasional Paper No.201: 10, 16. Zoological Survey of India, Kolkata, 37pp.

Anonymous (2004). Final Report on Preliminary Study on Biodiversity of Sewage EFD Fisheries of East Kolkata Wetland Ecosystem. Submitted to Deptt. of Environment, Govt. of W.B. by Institute of Wetland Management \& Ecological Design, Salt Lake City, Kolkata, 40pp.

Baillie, J. \& B. Groombridge (compilers and eds.) (1996). 1996 IUCN Red List of Threatened Animals. IUCN, Gland, Switzerland.

Biswas, B. (1969). Unpublished records of Zoological Survey of India [Quoted by Ghosh (1990)].

Biswas, K.P. (1927). Flora of the Salt Lakes, Calcutta. Journal of Department of Science. University of Calcutta 8: 1-48.

CBSG, India (2000). Herpestes palustris. In: IUCN 2007. 2007 IUCN Red List of Threatened Species. <www.iucnredlist.org > Downloaded on $2^{\text {nd }}$ January 2008.

Chakraborty, S. (1989). Mammals, p. 327. In: Majupuria, Trilok Chandra (ed.). Wildlife Wealth of India (Resources $\mathcal{E}^{2}$ Management). Tecpress Service, L.P., Bangkok, Thailand, 667pp.

Chattopadhyay, K. (2001). Environmental Conservation and Valuation of East Calcutta Wetlands. Indira Gandhi Institute of Developmental Research, Goregaon, Mumbai, 56pp.

Cook, C.D.K. (1996). Aquatic and Wetland Plants of India. Oxford University Press New Delhi, 392pp.

Corbet, G.B. \& J.E. Hill (1992). The Mammals of the Indomalayan Region. A Systematic Review. Oxford University Press, Oxford, United Kingdom, Viii+488pp.

Dasgupta, R. (1973). Contribution of Botany of a portion of Salt Lakes, West Bengal. Indian Museum Bulletin Calcutta 8(1): 36-43.

De, M., S. Bhunia \& T. Sengupta (1989). A preliminary account on major wetland fauna of Calcutta and its surroundings. Ecology 3(9): 5-11.

Dey, P. (2007). Study on Marsh Mongoose (Herpestes palustris, Ghose) in the East Kolkata wetland. Environ 10(4): 31-33.

Ellerman, J.R. \& T.C.S. Morrison-Scott (1951). Checklist of Palaearctic and Indian Mammals, p. 279. Brit. Bus. (Nat. Hist.), London, 810pp.

Ewer, R.F. (1997). The Carnivores, pp. 196, 311, 405. Cornell University Press, 544pp.

Ghose, R.K. (1965). A new species of Mongoose (Mammalia: Carnivora: Viverridae) from West Bengal, India. Proceedings of Zoological Society of Calcutta 18(2): 174-178.

Ghose, R.K. \& Y. Chaturvedi (1973). Extension of range of the mongoose, Herpestes palustris Ghose (Mammalia:Carnivora:Viverridae), with note on its endoparasitic nematode. Journal of Bombay Natural History Society 69(2): 412-413.

Ghosh, A.K. (1990). Biological Resources of wetlands of East Calcutta. Indian Journal of Landscape System and Ecological Studies 13(1): 10-23.

Ghosh, A.K. (1997). Management of East Calcutta Wetlands and Canal System. Dept. of Environment, Govt. of West Bengal assisted by the UK, Overseas Development Administration, Unpublished.

Ghosh, A.K. (2004). Avian Diversity in East Calcutta Wetlands. Environ $9(1): 8-13$. 
Ghosh, S.K. \& D. Ghosh (2003). Rehabilitating Biodiversity: A community based initiative in the East Calcutta Wetlands. WWF-India (West Bengal State Office), Kolkata, 40pp.

Hilton-Taylor, C. (compiler) (2000). 2000 IUCN Red List of Threatened Species. IUCN, Gland, Switzerland and Cambridge, UK.

Honacki, J.H., K.E. Kinman \& J.W. Koeppl (eds.) (1982). Mammal Species of the World. Allen Press Inc. and Assoc. Syst. Colln., Kansas. 694pp.

Hussain, S.A. (1999). Mustelids, Viverrids and Herpestids of India: Species Profile and Conservation Status. In: Hussain, S.A. (ed.). ENVIS Bulletin:Wildlife and Protected Areas, Mustelids, Viverrids and Herpestids of India 2(2): 27-28. Wildlife Institute of India, Dehradun, 148pp.

MacDonald, D.W. (2001). The New Encyclopedia of Mammals. Oxford University Press, 936pp.

Mallick, J.K. 2007. Endemic mammals of West Bengal. West Bengal ( $A$ West Bengal Government English Monthly, Kolkata) 49(10\&11): 53-55.

Molur, S., P.O. Nameer \& S. Walker (eds.) (1998). Report of the Workshop "Conservation Assessment and Management Plan (C.A.M.P.) for Mammals of India” (BCPP-Endangered Species Project), 7, 17, 27. Zoo Outreach Organisation, Conservation Breeding Specialist Group, India. Coimbatore, India, 176pp.

Nandi, N.C., S.R. Das, S. Bhuinya \& J.M. Dasgupta (1993). Wetland Faunal Resources of West Bengal 1. North and South 24-Parganas Districts. Records of the Zoological Survey of India, Occasional Paper No. 150: 10. Zoological Survey of India, Kolkata. 50pp.

Nature Environment \& Wildlife Society, Kolkata (NEWS) (2006). Status and Conservation of the Marsh Mongoose, Herpestes palustris (Ghose). Project Report.September, 2005-March, 2006. Unpublished. $<$ www.naturewildlife.org/Publication.htm $>$ Downloaded on $2^{\text {nd }}$ January 2007.

Chowdhury, D.K.R. (1984). Birds in and around Calcutta Metropolitan area. Naturalist (Journal of Prakiti Samsad) 1: 7-16.

Sanyal, P. (1999). Status Report - 5 : Common Mustelids, Viverrids and Herpestids of West Bengal. Pp. 59-61. In: Hussain, S.A. (ed). ENVIS
Bulletin:Wildlife and Protected Areas, Mustelids, Viverrids and Herpestids of India 2(2): 60. Wildlife Institute of India, Dehradun, 148pp.

Schreiber, A., R. Wirth, M. Riffel \& H. Van Rompaey (eds). (1989). Weasels, Civets, Mongooses, and their Relatives. An Action Plan for the Conservation of Mustelids and Viverrids. IUCN/SSC Mustelid and Viverrid Specialist Group, Gland, Switzerland, 92pp.

Sen, D.N. (1941). Observation on the method of carp culture in the so called Salt Lake near Calcutta with a note on the fish fauna of the lakes. Journal of Royal Asiatic Society, Bengal Science 8: 7-13.

Sewel, R.B. (1934). A study of the fauna of Salt Lake, Calcutta. Record of the Indian Museum 36: 45-121.

Veron, G., M-L Patou, G. Pothet, D. Simberloff \& A.P. Jennings (2007). Systematic status and biogeography of the Javan and small Indian mongooses (Herpestidae, Carnivora). Zoologica Scripta 36(1): 1-10.

Walker, S. (1999). Endemic and non-endemic mammals in Indian zoos - from Central Zoo Authority Data Base 1998 and BCPP CAMP Workshop Output. Part III - Civets and Mongooses of India. Zoos' Print 14(8): 7-18.

Walker, S. \& S. Molur (1999). Captive Breeding and Trade - I : Conservation Breeding and Indian Species of Mustelids, Viverrids and Herpestids : A Perspective. In: Hussain, S.A. (ed.). ENVIS Bulletin:Wildlife and Protected Areas, Mustelids, Viverrids and Herpestids of India 2(2): 108. Wildlife Institute of India, Dehradun, 148pp.

Wenzel, E. \& T. Haltenorth (1972). System der Schleichkatzen (Viverridae). Sugetierkundliche Mitteilungen 20(1-2): 110-127.

Wozencraft, W.C. (2005). Order:Carnivora, pp. 532-628. In: Wilson, D.E. \& D.M. Reeder (eds.). Mammal Species of the World ( $3^{\text {rd }}$ Edition). John Hopkins University Press, Baltimore and London, 2142pp. 